地 震 第 2 輯

第 58 巻 (2006) 375-384 頁

\title{
岩石圧縮破壊に伴うマイクロ波放射の観測
}

\author{
東京大学大学院工学系研究科* 牧 謙一郎 ${ }^{\dagger}$ \\ 宇宙航空研究開発機構宇宙科学研究本部** 高 野 忠 \\ 東京理科大学大学院工学系研究科*** 相馬央令子・石井健太郎 \\ 東京大学地震研究所**** 吉 田真吾・中谷正生
}

\section{An Experimental Study of Microwave Emissions from Compression Failure of Rocks}

\author{
Ken-ichiro MAKI ${ }^{\dagger}$ \\ School of Engineering, University of Tokyo, 7-3-1 Hongo, Bunkyo-ku, Tokyo 113-8654, Japan
}

Tadashi TAKano

Institute of Space and Astronautical Science, Japan Aerospace Exploration Agency, 3-1-1 Yoshino-dai, Sagamihara-shi, Kanagawa 229-8510, Japan

\section{Eriko Soma and Kentaro IsHII}

Faculty of Engineering, Tokyo University of Science, 1-3 Kagurazaka, Shinjuku-ku, Tokyo 162-8601, Japan

\section{Shingo Yoshida and Masao NAKatani}

Earthquake Research Institute, University of Tokyo, 1-1-1 Yayoi, Bunkyo-ku, Tokyo 113-0032, Japan

(Received January 5, 2005; Accepted December 15, 2005)

Electromagnetic emissions observed in a series of rock fracture tests are described. Four kinds of rocks, basalt, gabbro, granite and quartzite were pressed by uniaxial compression to fracture, for all of which many signals were detected at two microwave bands $(2 \mathrm{GHz}$ and $300 \mathrm{MHz}$ ). These detected signals consist of intermittent pulses of a short duration. Comparing the microwave records and the observation with a high-speed digital video camera, we found that the pulse signals were generated after the decrease of the axial load, and even after the macroscopic fracture (deformation) was completed. This differs from the occurrence of lower frequency emissions $(0.3-300 \mathrm{kHz})$ monitored as well, which became active and was strongest during the load decrease. The occurrence of signals at the two microwave bands did not always coincide, but a signal at $300 \mathrm{MHz}$ often followed a signal at $2 \mathrm{GHz}$ with a short interval of 50-100 ns. An additional detector at $22 \mathrm{GHz}$ picked up emissions only for quartzite, which occurred exclusively during the decrease of axial load.

Key words: Microwave emission, Rock fracture

* 干113-8654 東京都文京区本郷 7-3-1

** 干229-8510 相模原市由野台 3-1-1

*** $=162-8601$ 東京都新宿区神楽坂 1-3

**** $=113-0032$ 東京都文京区弥生 1-1-1
†現所属：理化学研究所テラヘルッイメージング研究 チーム

干980-0845 仙台市青葉区荒巻字青葉 519-1399

† Present Address: Terahertz Sensing and Imaging Laboratory, RIKEN, 519-1399 Aoba, Aramaki, Aoba-ku, Sendai, Miyagi 980-0845, Japan 


\section{§1.はじめに}

地震に伴う電磁場变動あるいは電磁放射が数多く報告 されている [例えば, Asada et al. (2001), Fraser-Smith et al. (1990), Gokhberg et al. (1982), Nagao et al. (2002), 吉田・西(2002)]. しかしその発生メカニズム は明らかになっていない，岩石破壊実験を行うことで, その放射特性, およびメカニズムの解明を目的とする研 究が多くなされている．提案されている放射メカニズム のひとつとして，岩石中に含まれる石英の圧電性に起因 するものがある．例えば Nitsan (1977) は，様々な岩石 を用いて破壊実験を行い, 圧電性をもつ岩石からのみ数 $\mathrm{MHz}$ 帯の電磁放射を検出した. Ogawa et al. (1985) は 岩石同士をぶつけるときに生じる電磁放射を調べ，圧電 効果が発生メカニズムのひとつの候補と推測している が，その他に接触電位差に基づくメカニズムの可能性に ついても論じている. また Ikeya and Takaki (1996), Yoshida and Ogawa (2004), Yoshida et al. (1994) は, 岩石破壊実験の結果に基づき，圧電による分極と岩石内 の補償自由電荷の両方の効果を考慮したモデル化を行 い，周波数特性などを定量的に議論した。

一方，圧電性を持たない岩石の破壊に伴う電磁放射む 観測されている. Yamada et al. (1989) は，岩石破壊に 伴う電磁放射とともに, 岩石中に生じる超音波振動を同 時観測した。伝播速度を補正すると両者の検出時刻がほ とんど一致することから, 微小亀裂が電磁放射と密接に 関係すると推測している，破壊による摩擦や亀裂生成に 伴う化学結合の切断により, 表面間で異符号の電荷が分 離され，亀裂表面で沿面放電による電流が流れ，電磁放 射に至るというモデルも提出されている [O'Keefe and Thiel (1995), O'Keefe et al. (2000), Takeuchi and Nagahama (2001)]. また, Takeuchi and Nagahama (2002) は花崗岩の摩擦すべり実験を行い，すべり始める 直前に電磁放射か観測されたとして圧電効果以外のメ力 ニズムを考察しているが，変位や荷重の測定系について 周波数特性は記載されてない. Cress et al. (1987) は岩 石が破壊する際の光，および $900 \mathrm{~Hz}$ から $500 \mathrm{MHz}$ 以 上までの電磁放射の測定から，周波数帯によっては破壊 時ではなく破壊後に検出されるあのああることを示し， エキソ電子放射により帯電した小破片が dust のように 噴き出ることによる現象であると考えた．Freund (2000) も岩石に対して衝突実験を行い，衝突後に電荷が 蓄積し電磁放射が起こる現象を見いだし，正孔が移動す るモデルにより説明を試みた。

以上述べた各測定は, Cress et al. (1987) を除けば，観 測周波数帯は $\mathrm{DC}$ から数百 $\mathrm{MHz}$ までか, あるいは光の 帯域であり, GHz 帯のマイクロ波帯域での観測例は極
めて少ない. 例外的に Geng et al. (1999) は，マイクロ 波帯で岩石破壊時の電磁放射を観測している．ただし測 定は放射計（ラジオメータ）によっているため時間分解 能が低く, 応力による輝度温度の準静的変化をみただけ である．電磁放射の原因としてすでに提案されている圧 電気の解放や，岩石亀裂での沿面放電による電磁放射の 場合，その時定数は $130 \mu \mathrm{s}$ 程度であり [O'Keefe and Thiel (1995)], このような遅い現象によって, GHz 帯で あるマイクロ波が放射されるとは考えにくい，したがっ て岩石破壊に伴うマイク口波放射の観測は，電磁放射の 原因を明らかにする有力な手段のひとつ之考えられる。 その際, マイクロ波を十分な時間分析能で観測すること により，放射原因の持続時間がわかり，ひいては放射原 因の特定につながると期待できる.

物質の破壊に伴う電磁放射現象としては，金属への超 高速衝突によるマイクロ波発生が観測されている [Takano et al. (2002)]. この場合, 金属分子が熱解離し て, プラズマ振動が発生することも考えられる. Bianchi et al. (1984) および Crawford and Shultz (1991) は超高速衝突実験により, 岩石への衝突でプラズ マが生成されることを示した. Martelli et al. (1989) は 花岡岩や玄武岩の破壊実験を行い，ラングミュアプロー ブを用い破壊時にプラズマ放射を検出した，彼らは 2 $\mathrm{kHz}$ 帯の電磁放射屯検出しているが，マイクロ波は測定 していないので, マイクロ波が発生するほどプラズマ密 度が高かったかどうかはわからない，また，Kamogawa and Ohtsuki (1999) は地殼内部でのプラズマ振動につ いて論じた.

本研究では，岩石破壊に伴うマイクロ波放射を観測 し，その特性を実験的に解明することを目的とする．放 射は広帯域に及ぶと予測し， $300 \mathrm{MHz}, 2 \mathrm{GHz}, 22 \mathrm{GHz}$ の 3 つの周波数帯で観測し，それぞれに適した受信系の 選択，および較正を行う。できるだけ多くの周波数帯で の測定が望ましいが，測定器などの関係から離散的な周 波数帯で測定した. また, 0.3 300 kHz の低周波帯での 放射も同時観測し，マイクロ波との比較を行う．検出信 号を $1 \mathrm{GHz}$ の高サンプリングで記録し，現象を時間的 にできるだけ精密に捕える，岩石試料には石英の含有率 の異なるむのを用いて，放射特性の違いを調べる，さら に，高速ディジタルビデオカメラにより岩石の破壊・変 形の様子を撮影し，電磁放射之破壊過程との時間的関係 を調べる。

\section{§ 2. 実験装置構成}

岩石の破壊にはFig. 1 に示す油圧サーボ制御式一軸 圧縮試験機を使用する．Fig. 1 のように，ステージに置 


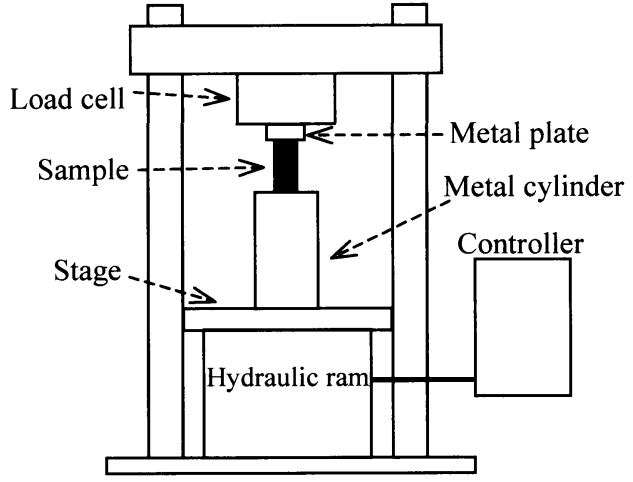

Fig. 1. Schematic illustration of loading apparatus.

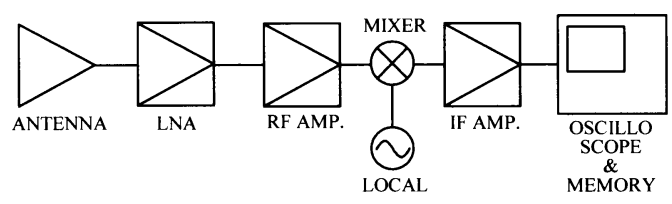

$\mathrm{RF}$ : radio frequency, IF : intermediate frequency LNA: low noise amplifier

Fig. 2. Block diagram of heterodyne receiving system.

かれた金属円柱上に岩石試料を設置する。試料上部には 厚さ $1 \mathrm{~cm}$ の金属円盤が接着される. 荷重は金属円盤上 部のロードセルで計測され，その時定数は $0.3 \mathrm{~ms}$ であ る.試料の変位はステージの動きとして計測され，その 時定数は約 $0.5 \mathrm{~s}$ である. 岩石への加圧速度は変位量で $0.08 \mathrm{~mm} / \mathrm{s}$ である。

実験に供した岩石は, 石英が 9 割を占める珪岩（愛知 県額田産), 石英が 3 割を占める花崗岩 (茨城県稲田 産), 石英を含まない玄武岩 (兵庫県豊岡産) と斑レイ岩 （山口県高山産）の 4 種類である. 試料形状は, 直径 27 $\mathrm{mm}$, 高さ $60 \mathrm{~mm}$ の円柱形である. 破壊時における岩 石破片の散乱を防ぐため, 試料側面全体をビニールテー プで被う。

マイクロ波放射観測の受信周波数帯は $22 \mathrm{GHz}, 2$ $\mathrm{GHz}, 300 \mathrm{MHz}$ の 3 つである. $22 \mathrm{GHz}, 2 \mathrm{GHz}$ 帯につい ては, Fig. 2 に示すへテロダイン検波受信系を採用し, マイクロ波信号 $(\mathrm{RF})$ を混合器 (MIXER) に掛けて中間 周波数信号 (IF) に変換する [Takano et al. (2002)]. 300 $\mathrm{MHz}$ 帯および同時観測する低周波帯 $(0.3 \sim 300 \mathrm{kHz})$ の 受信系は, アンテナ, 増幅器 (AMP) と帯域通過フィル夕 (BPF) で構成される，感度を高めるために，すべての受 信系に低雑音増幅器 (LNA) を含める.

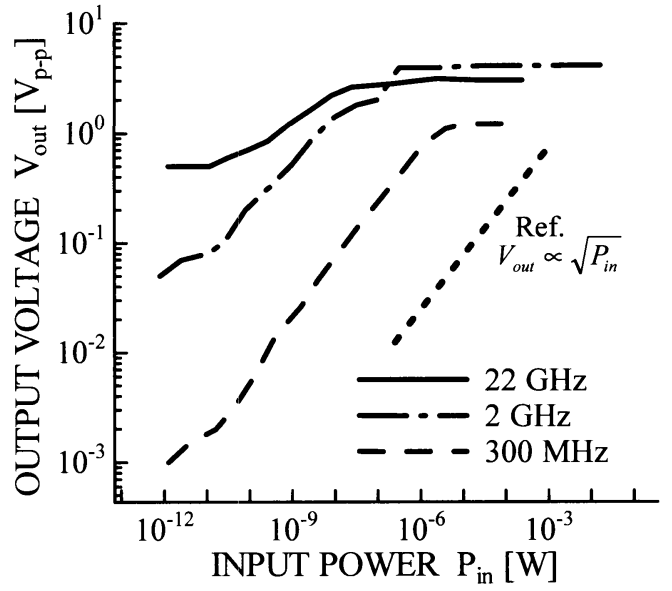

Fig. 3. Output voltage versus input power of the receivers. A dotted line indicates a linear characteristic.

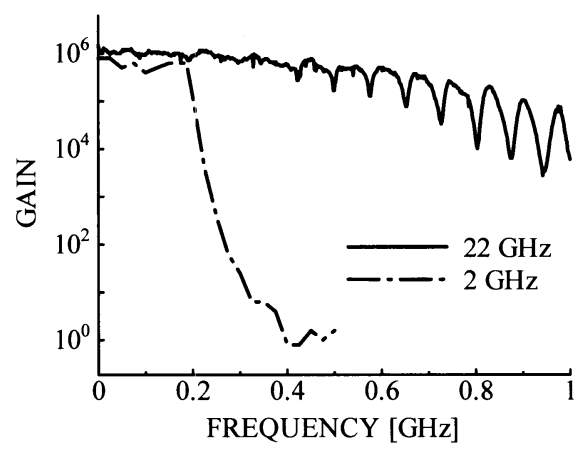

Fig. 4. Gain versus intermediate frequency of the receivers for $2 \mathrm{GHz}$ and $22 \mathrm{GHz}$ bands.

Fig. 2 で示されるマイクロ波受信系において，アンテ ナ直後の系に, 単一の周波数をもつ連続信号を入力し, 入力電力に対する出力電圧を較正する. Fig. 3 に 3 周波 数帯における較正結果を示す. 図中の点線 (Ref.) は線形 な特性を表す. 各周波数帯の受信系において, 非線形性 が現れている. 出力電圧は $3.1 V_{\mathrm{p}-\mathrm{p}}(22 \mathrm{GHz}$ 帯), $4.0 V_{\mathrm{p}-\mathrm{p}}\left(2 \mathrm{GHz}\right.$ 帯), $1.2 V_{\mathrm{p}-\mathrm{p}}(300 \mathrm{MHz}$ 帯) で飽和す る. 検出可能な最小電力は, 通常時の雑音電圧によって 決定され，その值は， $10^{-11} \mathrm{~W}\left(22 \mathrm{GHz}\right.$ 帯), $10^{-12} \mathrm{~W}$ (2 $\mathrm{GHz}$ 帯), $10^{-10} \mathrm{~W}(300 \mathrm{MHz}$ 帯) である. $22 \mathrm{GHz}$ 帯, $2 \mathrm{GHz}$ 帯, および $300 \mathrm{MHz}$ 帯の受信機利得の周波 数特性をそれぞれ Fig. 4 と Fig. 5 に示す.これより受 信系の帯域が求められ, Table 1 にまとめる.

受信アンテナおよび高速ビデオカメラの配置を Fig. 6 に示す。マイクロ波帯観測用受信アンテナには, ホーン アンテナ (22 GHz 帯), 対数周期アンテナ (2 GHz 帯), 


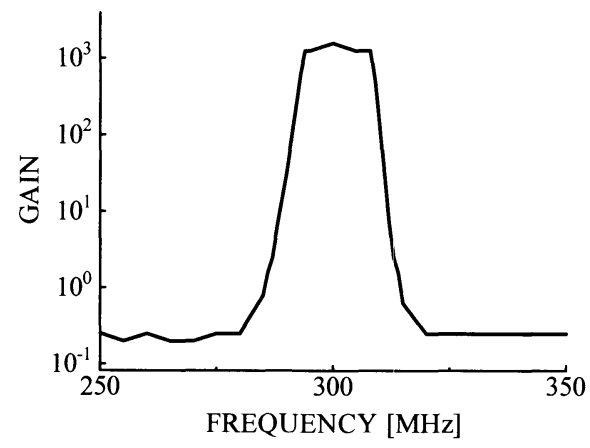

Fig. 5. Gain versus frequency of the receiver for a $300 \mathrm{MHz}$ band.

Table 1. The radio and intermediate frequency band characteristics of the receiving systems.

\begin{tabular}{|c|c|}
\hline RF band & IF band \\
\hline $22-23 \mathrm{GHz}$ & $0-500 \mathrm{MHz}$ \\
\hline $1.94-2.24 \mathrm{GHz}$ & - \\
\hline $292-309 \mathrm{MHz}$ & - \\
\hline $0.3-300 \mathrm{kHz}$ & - \\
\hline
\end{tabular}

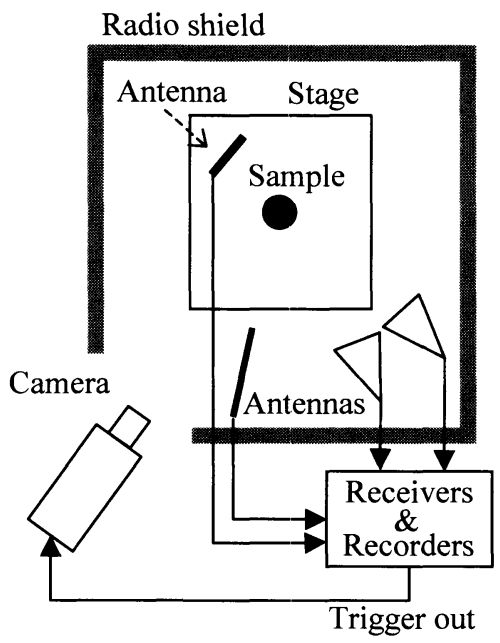

Fig. 6. Experimental layout.

ループアンテナ (300 MHz 帯) を用い, 岩石試料との距 離はそれぞれ, $48 \mathrm{~cm}, 34 \mathrm{~cm}, 68 \mathrm{~cm}$ である. また, 低周 波帯 $(0.3 \sim 300 \mathrm{kHz})$ の観測には $45 \mathrm{~mm} \times 45 \mathrm{~mm}$ の銅 箔アンテナを用い, 岩石から $10 \mathrm{~cm}$ の位置に設置して
電界変動を観測する。 また，外部からの雑音を遮断する ため, 試料およびアンテナのほぼ全体を電波広帯域吸収 体（各周波数帯での吸収は $300 \mathrm{MHz}$ : $-6 \mathrm{~dB}, 2 \mathrm{GHz}$ : $-13 \mathrm{~dB}, 22 \mathrm{GHz}:-50 \mathrm{~dB})$ で被う.

マイクロ波帯信号用の記録装置にはサンプリング周波 数 $1 \mathrm{GHz}$ ，観測時間 $4 \mathrm{~ms}$ のディジタルオシロスコープ を用いる．限られた観測時間内であ確実に信号を捕える ために，3つのマイクロ波帯信号電圧のいずれかが，設 定された閾值（トリガ電圧）以上になる時点で波形の記 録を開始させる，閾值は雑音電圧よりわずかに高い 0.30 $\mathrm{V}(22 \mathrm{GHz}$ 帯), $48 \mathrm{mV}$ (2 GHz 帯), $4.8 \mathrm{mV}$ (300 MHz 帯) に設定する.

マイクロ波記録用オシロスコープで発生する観測トリ ガ信号は, 以下の 3 つの観測機器へ出力される. (1) 0.3 〜 $300 \mathrm{kHz}$ 信号記録用ディジタルオシロスコープ（サン プリング周波数 $100 \mathrm{kHz}$, 観測時間 $1 \mathrm{~s})$, (2) 荷重, 変位 測定用パーソナルコンピュータ（サンプリング周波数 2 $\mathrm{kHz}$ ，(3) 高速ディジタルビデオカメラ（分解能 $74 \mu \mathrm{s}$, 観測時間 $0.91 \mathrm{~s}$ ). トリガ信号を出力することにより,す べての測定信号を同期させる，また，高速力メラからは 撮影開始を表す同期信号を出力し，記録することで，受 信系との同期を可能とする.

\section{§3. 各種岩石におけるマイクロ波放射}

実験は各岩石試料について 3 回（花崗岩のみ 4 回）行 われた. 高速ビデオカメラによる岩石破壊状況の撮影は 各岩石につき 1 回ずっ行った.この撮影により, 岩石試 料に亀裂が入り变形する様子が観測された。一例とし て, Fig. 7 に変形前後の班レイ岩の撮影画像とその詳細 を表すスケッチを示す．円柱の岩石中に斜めに亀裂が 入っている. ただしこの場合, 全体をビニールテープで 巻いているので, 破壊後に試料片が飛散することはな い.

Fig. 8 に珪岩での観測結果の一例を示す．この場合観 测トリガは $300 \mathrm{MHz}$ 帯の小さいパルスでかかってお り，その発生時刻を $0 \mathrm{~s}$ としてる. Fig. 8(a) で示す荷 重は，時刻一 $0.05 \mathrm{~ms}$ 付近から急激に降下し始め（図中 A), 時刻 $0.1 \mathrm{~ms}$ で極小值をとっている. 荷重降下後, 約 $2 \mathrm{~ms}$ にわたり荷重が変動している(図中 B).これ は，ロードセルまたはプレスの共振によるものであると 考えられる. 変位計による記録 $(F i g .8(f))$ では変形は 10 $\mathrm{ms}$ 続いているように見えるが, 変位計の計測システム の時定数が $0.5 \mathrm{~s}$ なので, 周波数特性の補正をしないと 正しい変形終了時刻は求められない. しかし, 試料の巨 視的变形の高速ビデオカメラ観察から, 破壊に伴う高速 な圧縮変形の開始，および主破壊の終了時刻をコマ送り 
(a)

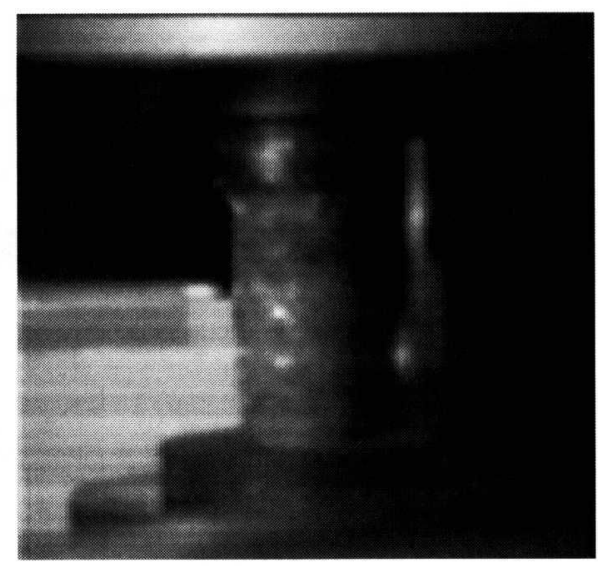

(c)

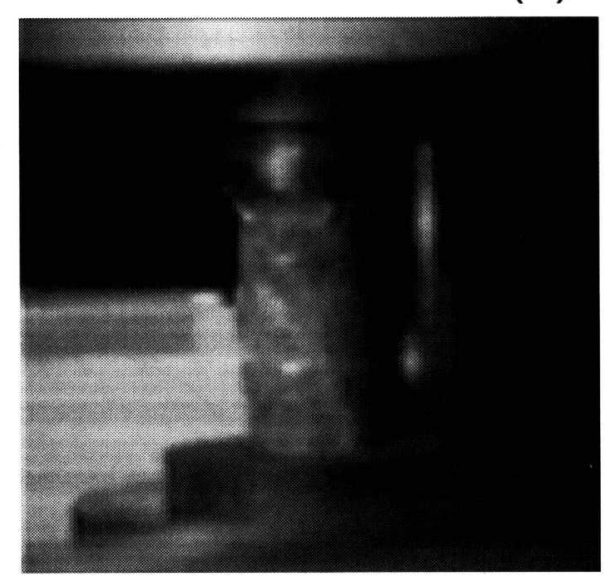

(b)

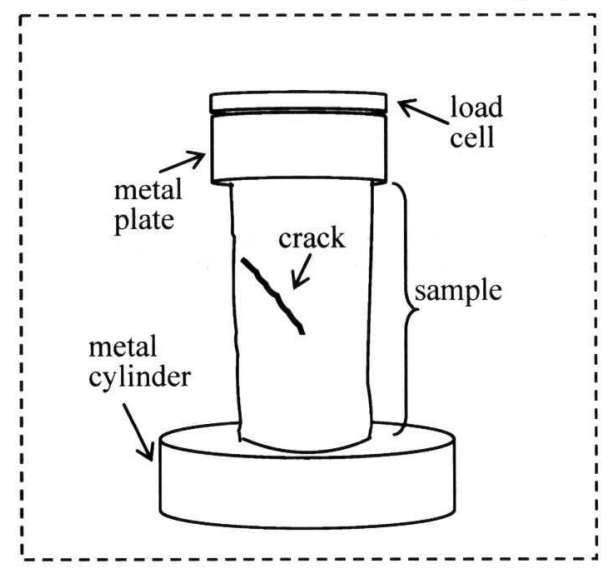

(d)

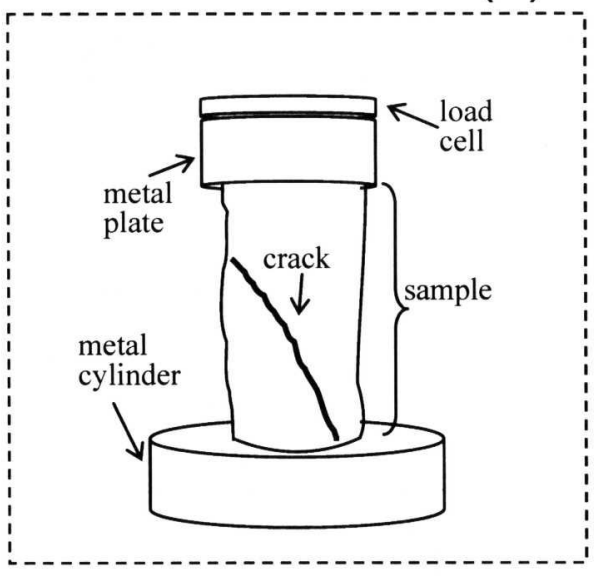

Fig. 7. The images of gabbro sample taken with a high-speed digital video camera: (a) photo and (b) sketch before fracture, (c) photo and (d) sketch after fracture.

精度 $(74 \mu \mathrm{s})$ で同定でき, 本実験の場合, 試料の変形は一 $0.2 \mathrm{~ms}$ から始まり $0.9 \mathrm{~ms}$ に終わったことがわかった. ただし，巨視的な主破壊終了後に試料内部で局所的な破 壊が起こっている可能性はある。

Fig. 8(b) で示す $22 \mathrm{GHz}$ 帯では, 図中C で示される信 号が，時刻 $-0.05 \mathrm{~ms}$ から $0.05 \mathrm{~ms}$ まで見られる。この 信号は詳しく見ると断続的に生起するパルスであり, 発 生時刻を Fig. 8(a) の荷重ロード変化と比較すると, 荷 重降下中に放射されたことがわかる。 また， $22 \mathrm{GHz}$ 帯 の信号が検出されたことから，時定数 $0.05 \mathrm{~ns}$ の高速な 現象が発生していることがわかる。これ以外に，バック グラウンドノイズよりも高い信号は確認できない，Fig. 8(c) の $2 \mathrm{GHz}$ 帯信号もやはり断続的なパルスである.
まず時刻 $-0.05 \sim 0.05 \mathrm{~ms}(22 \mathrm{GHz}$ 帯信号と同時刻) に パルス群が見える. 荷重降下後にも断続的パルスが複数 観測されており (図中 D), 時刻 $3.5 \mathrm{~ms}$ 付近に最も高い 信号がある (図中E). Fig. 8(d) の $300 \mathrm{MHz}$ 帯でも区間 $\mathrm{F}$ に扔いて, 荷重降下後の断続的なパルスが多数確認で きる。いくつかの信号は次節で詳述するように $2 \mathrm{GHz}$ 帯のパルス信号と同期しているが，Fig. 8(b) 中Cに相 当する時間では $300 \mathrm{MHz}$ 帯のみ信号が極めて弱い．ま たビデオカメラによる観察から主破壊の終了時刻は 0.9 $\mathrm{ms}$ であることがわかっているので, $2 \mathrm{GHz}$ と $300 \mathrm{MHz}$ 帯のパルスは荷重降下中だけでなく, 荷重が降下したあ 之剪断破壊面に沿ってすべりながら圧縮変形している 間，および巨視的破壊終了後も出続けていたことにな 

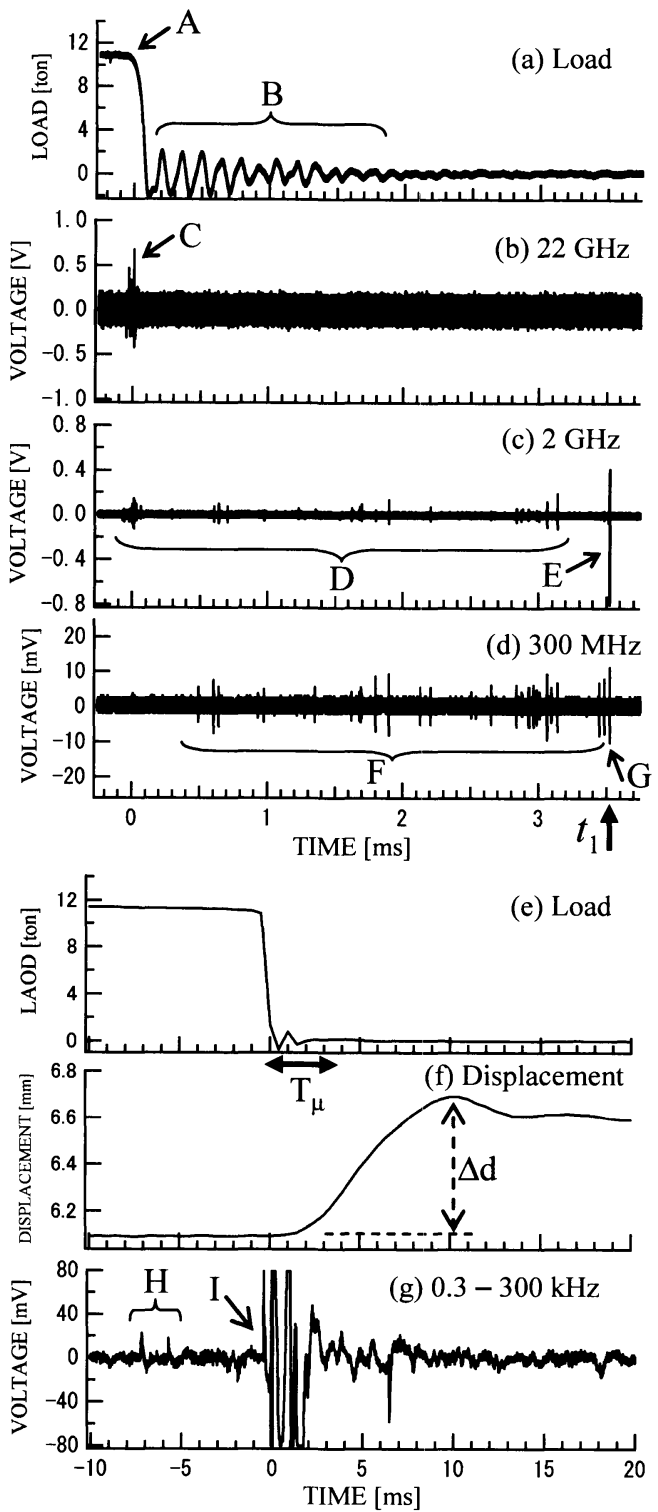

Fig. 8. Records from quartzite experiment: (a) load with high sampling, (b) voltage of microwave at $22 \mathrm{GHz}$ band, (c) $2 \mathrm{GHz}$ band, (d) $300 \mathrm{MHz}$ band, (e) load with low sampling, (f) displacement and ( $\mathrm{g}$ ) voltage of $0.3 \mathrm{k}-300 \mathrm{kHz}$ band. The measurement periods of (a) to (d) are correspondent to the period indicated by $T_{\mu}$ in (f). The moment when the microwave recorder was triggered is taken to be $0 \mathrm{~s}$. Labels with capital letters are referred in the text.
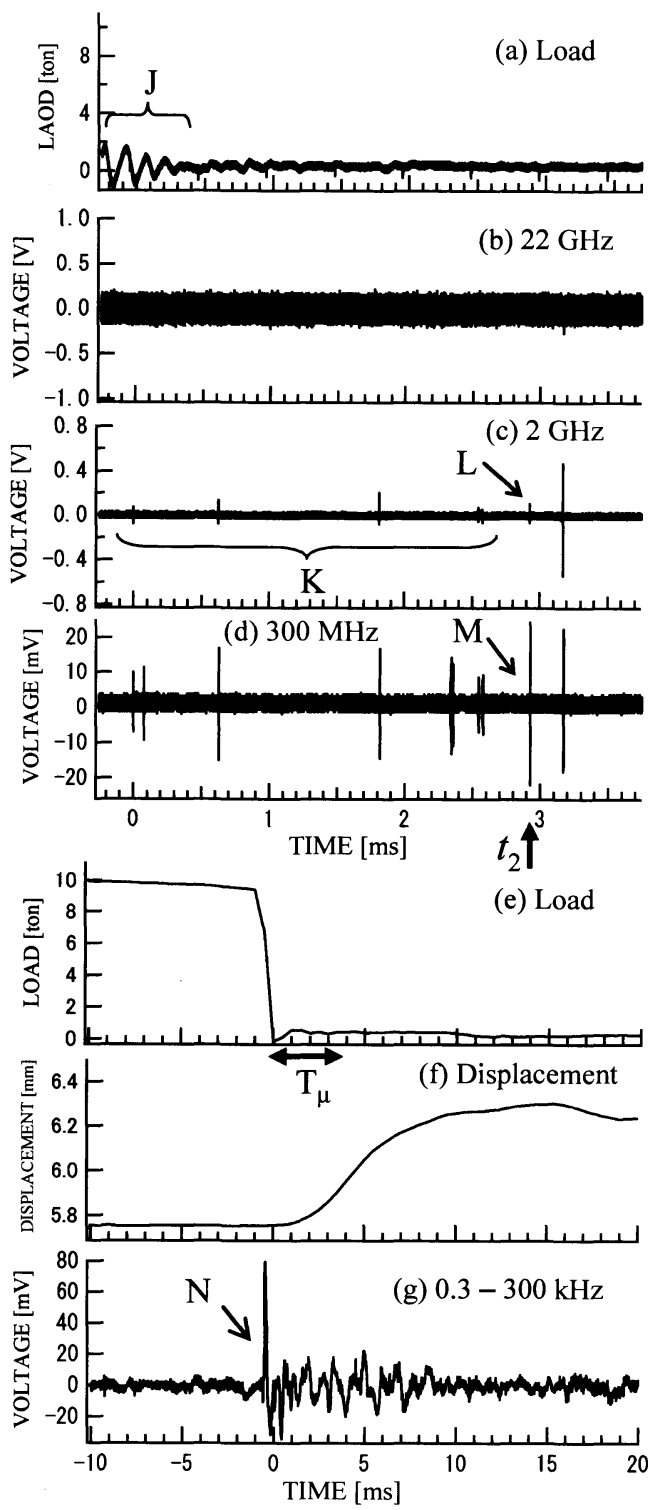

Fig. 9. The same as Fig. 8 except for gabbro.

る. 荷重降下中にマイクロ波が発生することや，その波 形の特徴は, 珪岩を用いた他の実験でも再現された。

$22 \mathrm{GHz}$ 帯, $2 \mathrm{GHz}$ 帯および $300 \mathrm{MHz}$ 帯で観測され た断続的なパルス状の信号は, 物体の超高速衝突の際も 観察されている [Takano et al. (2002)].

Fig. 8(e), (f), および (g) は時間軸を変えてあり，低サ ンプリングで計測された荷重，変位，および $0.3 \sim 300$ $\mathrm{kHz}$ 帯の低周波信号の変化をそれぞれ示す. Fig. 8(a) か ら (d) までの観測期間は, Fig. 8(f) 上の $T_{\mu}$ で示す区間に 相当する. 荷重が降下する前の時刻 $-7.2 \mathrm{~ms},-5.7 \mathrm{~ms}$ 
で，低レベルの低周波信号パルスが見られる（図中 $\mathrm{H}$ ). 荷重降下の始まりと同時に，高レベルの振動波形が現れ る(図中 I)。この部分の信号の始まりは，マイクロ波信 号と比べ約 $0.5 \mathrm{~ms}$ 速い. 周期 $0.02 \mathrm{~ms}$ (周波数 $50 \mathrm{kHz}$ ) から $0.8 \mathrm{~ms}$ (周波数 $1.3 \mathrm{kHz}$ ) の成分が複合した信号が, 時刻 $9 \mathrm{~ms}$ まで継続している.

本実験では試料をビニールテープで巻いて破壊させ た. テープの帯電の可能性は完全には否定できないが, ビデオによる観察からテープの剥離はほとんどなく，ま
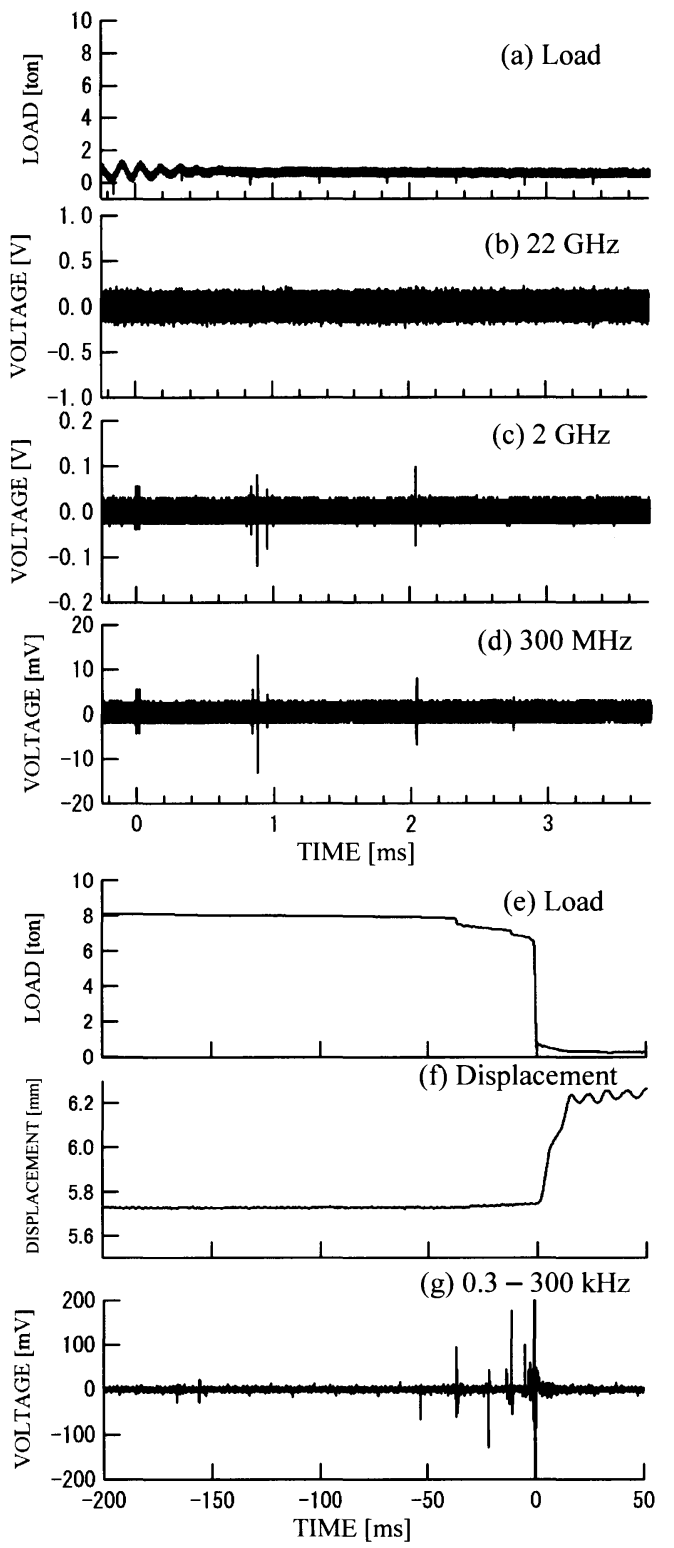

Fig. 10. The same as Fig. 8 except for granite.
た比較のためテープを巻かないで行った実験でも同様の マイクロ波が検出されたことから，本稿での議論につい てはテープの帯電の影響はないと考えられる.

斑レイ岩を用いた場合の荷重, マイクロ波信号, 変位, 低周波信号を，各々Fig. 9(a)から (g) に示す. トリガと なる信号が検出されたときに，斑レイ岩では荷重が完全 に降下し終わって抢り，珪岩で荷重が降下中であるの之 異なっている. $22 \mathrm{GHz}$ 帯では, 顕著な信号は確認され ない. $2 \mathrm{GHz}$ 帯と $300 \mathrm{MHz}$ 帯の信号は, 珪岩の場合と 同様に断続的なパルスであるが発生数は珪岩より少な

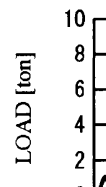

(a) Load
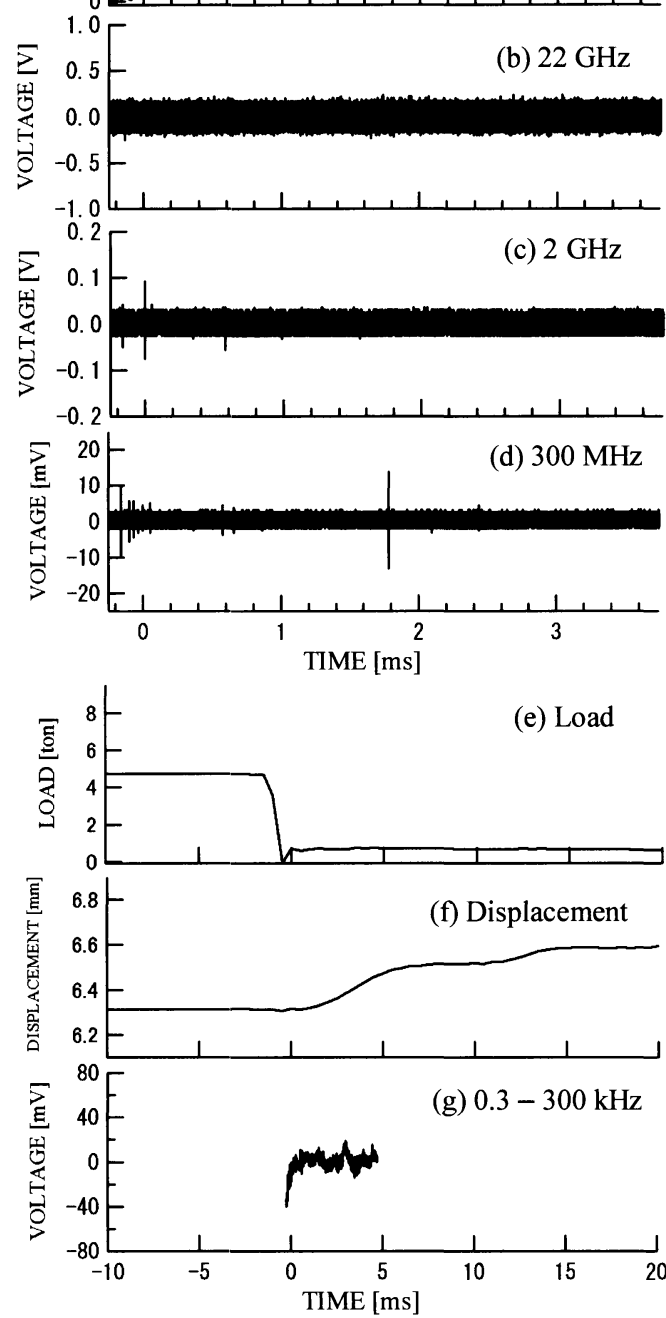

Fig. 11. The same as Fig. 8 except for basalt. 
い. Fig. 9(g) に示す $0.3 \sim 300 \mathrm{kHz}$ 信号では, マイクロ 波とは異なり，荷重降下中から信号が検出されているこ とが確認できる. 荷重が完全に降下し終わってからマイ クロ波が発生することや，その波形の特徴は，斑レイ岩 を用いた他の実験でも再現された.

花岡岩, 玄武岩についても，2 $\mathrm{GHz}$ 帯と $300 \mathrm{MHz}$ 帯 に扔いて断続的パルスのマイクロ波信号が検出されてい る. 各々のデータを Fig. 10 と Fig. 11 に示すが, ビデオ カメラによる観察との比較から，すべて主破壊が終了し た後に検出されたことがわかっている，放射レベルは， 珪岩や斑レイ岩に比べて低い. $22 \mathrm{GHz}$ 帯の信号は確認 されていない，0.3〜300 kHz 信号は，花崗岩ではマイク 口波検出時刻の $180 \mathrm{~ms}$ 前から検出された。玄武岩では タイムウィンドウの設定が適切でなかったため, マイク 口波検出時刻より前は記録できなかった。

石英の含有量の多いケイ岩と花崗岩に見られる 100 $\mathrm{mV}$ オーダーの $0.3 \sim 300 \mathrm{kHz}$ 信号は（珪岩は飽和して おり少なくとも $80 \mathrm{mV}$ 以上）応力変化中に発生してい ることから, 複数のメカニズムが働いている可能性はあ るが，少なくとも圧電効果が強く寄与していると考えら れる。

Cress et al. (1987) は破壊後の電磁放射の原因として, エキソ電子放射などにより帯電した岩石破片が dust 状 に吹き出すことを考えている. 今回は岩石試料をテープ で巻き付け，破片が飛び出さないようにして実験を行 い，高速ビデオカメラによる観察により dust が吹き出 なかったことを確認している．したがってこの説は本実 験に対しては妥当でないと思われる．巨視的な破壊が終 わってからあなぜマイクロ波が発生するかを明らかにす ることは, 今後の課題である.

本実験の結果から，地震のときむマイクロ波が放射さ れると考えられる. 地款の比抵抗が低いとスキンデプス の関係から地表まで伝播するのは難しいが，Yoshida and Ogawa (2004) の結果に基づけば, 例えば比抵抗が $50 \mathrm{k} \Omega \mathrm{m}$ の場合, $10 \mathrm{~km}$ より浅い震源からはマイクロ波 の方が低周波数帯の電磁波より伝播しやすい，また，地 中にマイクロ波の波長の半分程度以上の割れ目が入り, 導波管モードで伝播する可能性もある.

\section{§4. 各周波数帯における信号波形の詳細}

珪岩の場合, $22 \mathrm{GHz}$ 帯 (Fig. 8(b)) と $2 \mathrm{GHz}$ 帯 (Fig. 8 (c)), $300 \mathrm{MHz}$ (Fig. 8(d)) の各信号について, 拡大波形を Fig. 12 に示す. 信号は断続的に生起するパルスの集合 であり, パルス間隔は約 $0.2 \sim 4 \mu \mathrm{s}$ であることがわかる.

$22 \mathrm{GHz}$ 帯の信号は, 前述したように珪岩の主破壊中 のみに検出された．そのパルス状信号の時間軸を拡大し

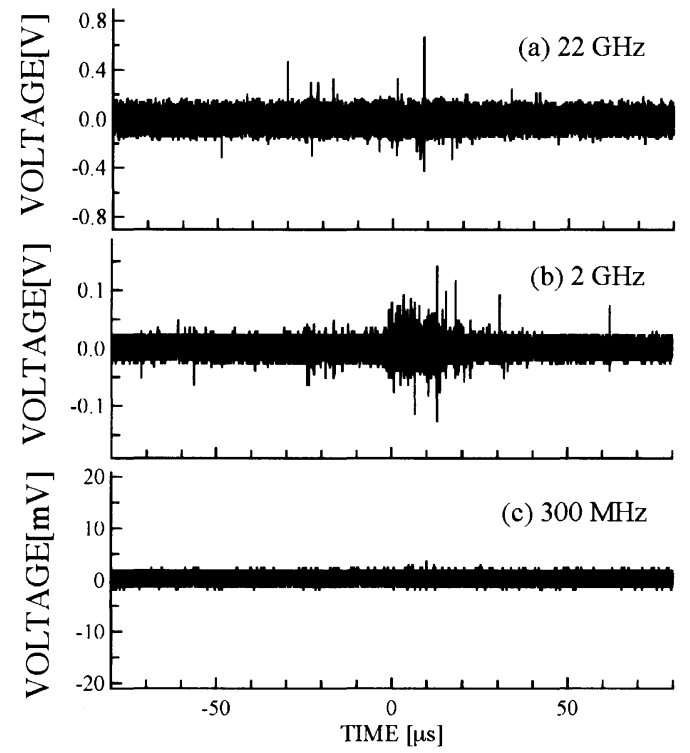

Fig. 12. Expanded view of microwave signals from quartzite.

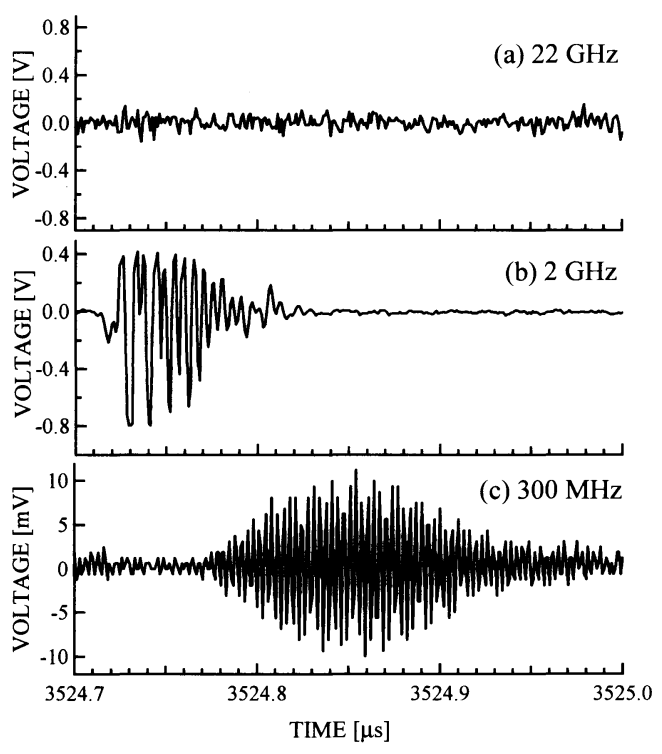

Fig. 13. Expanded waveforms from quartzite rock: (a) no signal at $22 \mathrm{GHz}$, (b) pulses at 2 $\mathrm{GHz}$ at $\mathrm{E}$ in Fig. 8, (c) pulses at $300 \mathrm{MHz}$ at $\mathrm{G}$ in Fig. 8.

て観たところ, 持続時間は約 $10 \mathrm{~ns}$ であることがわかっ た. $22 \mathrm{GHz}$ の信号が検出されたのと同時刻には, 2 $\mathrm{GHz}$ 帯と $300 \mathrm{MHz}$ 帯の信号は検出されていない.

主破壊後に検出された $2 \mathrm{GHz}$ 帯, および $300 \mathrm{MHz}$ 帯 の信号のひとつ (Fig. 8(c)の E および Fig. 8(d)の G)の 時間軸を拡大した図を Fig. 13 に示す. $2 \mathrm{GHz}$ 帯の信号 


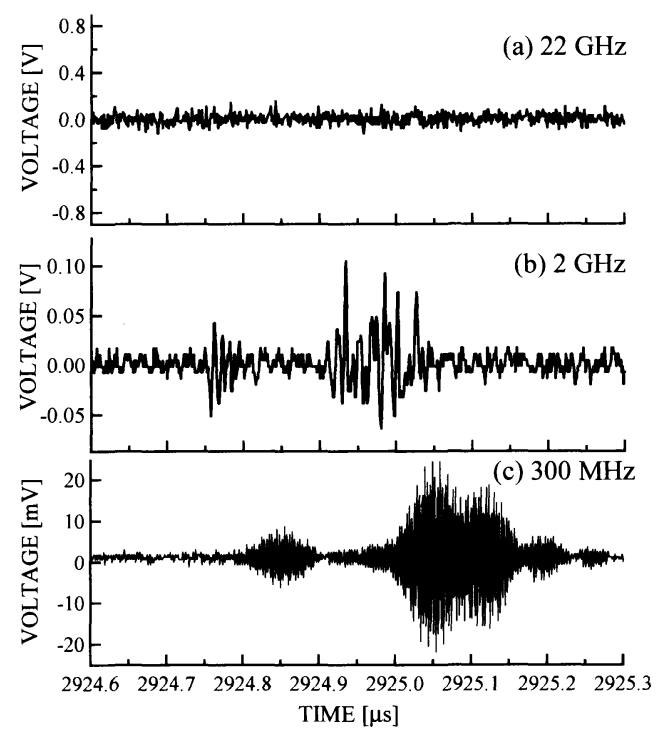

Fig. 14. Expanded waveforms from gabbro: (a) no signal at $22 \mathrm{GHz}$, (b) pulses at $2 \mathrm{GHz}$ in $\mathrm{L}$ in Fig. 9, (c) pulses at $300 \mathrm{MHz}$ in $\mathrm{M}$ in Fig. 9.

の持続時間は $0.1 \mu \mathrm{s}$ 程度, $300 \mathrm{MHz}$ 帯の信号の持続時 間は $0.2 \mu \mathrm{s}$ 以上あり, 長周期の信号の持続時間ほど長い 傾向が見られる.ただし, 試料の固有周波数が $2 \mathrm{GHz}$ 前 後なので, $2 \mathrm{GHz}$ 帯で得られた信号が固有振動も反映し ている可能性があり, 測定された持続時間は発生源の持 続時間の上限をみている. また, $2 \mathrm{GHz}$ の信号が検出さ れてから数十 ns 後に $300 \mathrm{MHz}$ の変動が現れているこ とがわかる.このような遅れの例は他にも多数あること から， $2 \mathrm{GHz}$ 放射と $300 \mathrm{MHz}$ 放射が独立な現象でたま たま数十 ns の間隔であったとは考えにくい. 電磁放射 の立ち上がり部分が $2 \mathrm{GHz}$ 成分を多く含み, その後長 周期成分に連続的に移行した，あるいは $2 \mathrm{GHz}$ 放射が $300 \mathrm{MHz}$ 放射を誘発する何らかのメカニズムが働いた， ということが考えられる.このことを調べるためには, $2 \mathrm{GHz}$ と $300 \mathrm{MHz}$ の間の屯っと多くの周波数帯で測定 する必要がある. また, $2 \mathrm{GHz}$ 帯だけで検出された例, $300 \mathrm{MHz}$ 帯だけで検出された例ああり, マイクロ波放 射メカニズムを明らかにすることは今後の課題である.

同じように, 斑レイ岩からのマイクロ波パルス信号 (Fig. 9(b), (c), (d)) を拡大して波形を見る. 斑レイ岩で は, $22 \mathrm{GHz}$ 帯で顕著な信号は検出されていない. 2 $\mathrm{GHz}$ 帯信号の典型として Fig. 9(c) の L, $300 \mathrm{MHz}$ 帯信 号を Fig. 9(d) の M として選び, 拡大波形をそれぞれ Fig. 14(b), (c) に示す. $2 \mathrm{GHz}$ 帯の信号の持続時間は 50 〜 $100 \mathrm{~ns}$ 程度, $300 \mathrm{MHz}$ 帯の信号の持続時間は 100〜
$200 \mathrm{~ns}$ 程度であり, 珪岩の波形と同様, 長周期の信号の 持続時間ほど長い傾向が見られる. また, $2 \mathrm{GHz}$ の信号 が検出されてから数十 ns 後に $300 \mathrm{MHz}$ の変動が現れ ている. 玄武岩, 花崗岩についても同様な放射が見られ た.

\section{§5. まとめ}

大気圧下で岩石 (玄武岩, 斑レイ岩, 花崗岩, 珪岩) を一軸圧縮破壊し, $22 \mathrm{GHz}, 2 \mathrm{GHz}, 300 \mathrm{MHz}$ 帯の各周 波数帯で, 破壊に伴った断続的なパルス状信号を検出し た. 高速ビデオカメラにより破壊過程を撮影し分析した 結果, いずれの岩石においても, $2 \mathrm{GHz}, 300 \mathrm{MHz}$ 帯の マイクロ波は, 岩石の巨視的な主破壊終了の後も数 $\mathrm{ms}$ 程断続的に発生し続けていたことを確認した. ただし， $22 \mathrm{GHz}$ 帯の信号は珪岩での荷重降下時のみ確認され た. $22 \mathrm{GHz}, 2 \mathrm{GHz}, 300 \mathrm{MHz}$ 帯のひとつひとつのパル ス状信号の持続時間は, 長周期帯ほど長くなる傾向が見 られた. また, $2 \mathrm{GHz}$ 帯信号の数十 ns 後に $300 \mathrm{MHz}$ 帯 信号が検出された例が多数あった。

マイクロ波の発生メカニズムは本実験からは特定でき ていない，何らかの原因で破壊に伴い電荷が発生し, 微 小亀裂の相対する面間で放電して微小ダイポール放射源 となればマイクロ波が発生しうるだろうが [牧・高野 (2004)], 特に, 巨視的な応力変化が終わってからもなぜ マイクロ波が発生するかを明らかにすることは, 今後の 課題である.

\section{謝 辞}

小河 勉氏と匿名の査読者および編集委員の田中 聡 氏から有益なご意見をいただきました，桑野 修氏には 実験を手伝っていただきました．記して感謝いたしま す.

\section{文献}

Asada, T., H. Baba, M. Kawazoe and M. Sugiura, 2001, An attempt to delineate very low frequency electromagnetic signals associated with earthquakes, Earth Planets Space, 53, 55-62.

Bianchi, R., F. Capaccioni, P. Cerroni, M. Coradini, E. Flamini, P. Hurrn, G. Martelli and P. N. Smith, 1984, Radiofrequency emissions observed during macroscopic hypervelocity impact experiments, Nature, 308, 830-832.

Crawford, D. A. and P. H. Schultz, 1991, Laboratory investigations of impact-generated plasma, J. Geophys. Res., 96, 18, 807-18, 817.

Cress, G. O., B. T. Brady and G. A. Rowell, 1987, Sources of electromagnetic radiation from fracture 
of rock samples in the laboratory, Grophys. Res. Lett., 14, 331-334.

Fraser-Smith, A.C., A. Bernardi, P. R. McGill, M.E. Ladd, R. A. Helliwell and O. G. Villard, Jr., 1990, Low-frequency magnetic field measurements near the epicenter of the $M_{S}$ 7.1 Loma Prieta earthquake, Geophys. Res. Lett., 17, 1465-1468.

Freund, F., 2000, Time-resolved study of charge generation and propagation in igneous rocks, J. Geophys. Res., 105, 11, 001-11, 019.

Geng, N., M. Deng and C. Cui, 1999, Simulated experimental studies on earthquake prediction by using infrared and microwave remote sensing, in "Atmospheric and Ionospheric Electromagnetic Phenomena Associated with Earthquakes", ed. by M. Hayakawa, Terrapub, Tokyo, 751-758.

Gokhberg, M. B., V. A. Morgounov, T. Yoshino and I. Tomizawa, 1982, Experimental measurement of electromagnetic emissions possibly related to earthquakes in Japan, J. Geophys. Res., 87, 78247828.

Ikeya, M. and S. Takaki, 1996, Electromagnetic fault for earthquake lightning, Jpn. J. Appl. Phys., 35, 355-357.

Kamogawa, M. and Y.H. Ohtsuki, 1999, Plasmon model for origin of earthquake related electromagnetic wave noises, Proc. Japan Acad. B, 75, 186189.

牧謙一郎・高野 忠, 2004, 衝突破壊に伴う放電による マイクロ波放射解析，電気学会全国大会，1-081.

Martelli, G., P. N. Smith and A. J. Woodward, 1989, Light, radiofrequency emission and ionization effects associated with rock fracture, Geophys. J. Int., 98, 397-401.

Nagao, T., Y. Enomoto, Y. Fujinawa, M. Hata, M. Hayakawa, Q. Huang, J. Izutsu, Y. Kushida, K. Maeda, K. Oike, S. Uyeda and T. Yoshino, 2002, Electromagnetic anomalies associated with 1995 Kobe earthquake, J. Geodyn., 33, 401-411.

Nitsan, U., 1977, Electromagnetic emission accompanying fracture of quartz-bearing rocks,
Geophys. Res. Lett., 4, 333-336.

Ogawa T., K. Oike and T. Miura, 1985, Electromagnetic radiations from rocks, J. Geophys. Res., 90, 6245-6249.

O'Keefe, S. G. and D. V. Thiel, 1995, A mechanism for the production of electromagnetic radiation during fracture of brittle materials, Phys. Earth Planet. Inter., 89, 127-135.

O'Keefe, S. G., D. V. Thiel and N. P. Davey, 2000, Fracture induced electromagnetic emissions in the minig industry, Int. J. Appl. Electromag. Mech., 12, 203-209.

Takano, T., Y. Murotani, K. Maki, T. Toda, A. Fujiwara, S. Hasegawa, A. Yamori and H. Yano, 2002, Microwave emission due to hypervelocity impacts and its correlation with mechanical destruction, J. Appl. Phys., 92, 5550-5554.

Takeuchi, A. and H. Nagahama, 2001, Voltage changes induced by stcik-slip of granites, Geophys. Res. Lett., 28, 3365-3368.

Takeuchi, A. and H. Nagahama, 2002, Interpretation of charging on fracture or frictional slip surface of rocks, Phys. Earth Planet. Inter., 130, 285-291.

Yamada, I., K. Masuda and H. Mizutani, 1989, Electromagnetic and acoustic emission associated with rock fracture, Phys. Earth Planet. Inter., 57, 157168.

Yoshida, S. and T. Ogawa, 2004, Electromagnetic emissions from dry and wet granite associated with acoustic emissions, J. Geophys. Res., 109, B09204, doi: 10.1029/2004JB003092.

Yoshida, S., P. Manjgaladze, D. Zilpimiani, M. Ohnaka and M. Nakatani, 1994, Electromagnetic emissions associated with frictional sliding of rock, in "Electromagnetic Phenomena Related to Earthquake Prediction”, ed. by M. Hayakawa and Y. Fujinawa, Terrapub, Tokyo, 307-322.

吉田彰顕・西 正博, 2002, 2000 年鳥取県西部地震抽 よび 2001 年芸予地震に関連した VHF 帯電磁現象の 観測, 地震 2, 55, 107-118. 